\title{
EFEKTIVITAS PEMBERIAN OBAT TUBERKULOSIS PADA PASIEN PEREMPUAN DEWASA RAWAT JALAN DI RUMAH SAKIT ISLAM ASSHOBIRIN TAHUN 2016
}

\author{
Nur Hasanah \\ Sekolah Tinggi Ilmu Kesehatan Kharisma Persada \\ Tangerang Selatan, 15417 \\ E-mail: nurhasanahbik51@gmail.com
}

\begin{abstract}
ABSTRAK
Tuberkulosis (TB) adalah salah satu penyebab utama mortalitas dan morbaditas di Indonesia. Penelitian ini bertujuan mengetahui efektivitas pemberian obat pada pasien tuberculosis terhadap jumlah bakteri penyebab TB (Micobacterium tuberculosis) dan laju endap darah passien. Penelitian ini bersifat deskriptif dan pengambilan data dilakukan secara retrospektif dari catatan medis pasien yang terdiagnosa tuberkolosis pada instalasi di rawat jalan Rumah Sakit Islam Asshobirin periode Januari-Desember 2016. Data dianalisis dengan menggunakan metode deskriptif kuantitatif. Sampel yang diambil pada penelitian ini adalah pasien perempuan dengan jumlah pasien sebanyak 40 pasien. Hasil penelitian menunjukan bahwa persentase penggunaan obat tuberkulosis di Rumah Sakit Islam Asshobirin selama tahun 2016 adalah Rifampisin sebanyak 30,77\%, Isoniazid 30,77\%, Etambutol 22,11\%, Pirazinamid 16,35\%. Efektivitas obat Tuberkulosis berdasarkan penurunan jumlah Micobacterium tuberculosis, pada penelitian ini menunjukkan bahwa Rifampisin mampu menurunkan jumlah bakteri sebanyak 196cfu/ml, Isoniazid $213 \mathrm{cfu} / \mathrm{ml}$, Etambutol 311 cfu/ml, Pirazinamid $218 \mathrm{cfu} / \mathrm{ml}$. Sedangkan efektivitas obat Tuberkulosis berdasarkan kemampuan menurunkan laju endap darah (LED) menunjukkan bahwa Rifampisin mampu menurunkan LED sebesar 46.5 $\mathrm{mm} / \mathrm{jam}$, Isoniazid $42.3 \mathrm{~mm} / \mathrm{jam}$, Etambutol $49.5 \mathrm{~mm} / \mathrm{jam}$, Pirazinamid 48,5 mm/jam. Obat TB yang paling efektif menurunkan jumlah Micobacterium tuberculosis dan laju endap darah adalah Etambutol.
\end{abstract}

Kata Kunci: Tuberkulosis, TB Paru, LED, Obat TB

\begin{abstract}
Tuberculosis $(T B)$ is one of the major causes of mortality and morbidity in Indonesia. This study aims to determine the effectiveness of drug administration in tuberculosis patients based on the number of TB-causing bacteria (Micobacterium tuberculosis) and patients's blood rate. This study is descriptive and retrospective data retrieval from medical records of patients diagnosed with tuberculosis at an outpatient installation of Asshobirin Islamic Hospital from January to December 2016. The data were analyzed by using quantitative descriptive method. Samples taken in this study were female patients with a total of 40 patients. The results showed that the percentage of tuberculosis drug use at Asshobirin Islam Hospital during 2016 was Rifampin as much as $30.77 \%$, Isoniazid 30,77\%, Etambutol 22,11\%, Pirazinamid 16,35\%. The effectiveness of Tuberculosis drug based on decreasing number of Micobacterium tuberculosis, in this study showed that Rifampicin able to reduce the number of bacteria as much as $196 \mathrm{cfu} / \mathrm{ml}$, Isoniazide $213 \mathrm{cfu} / \mathrm{ml}$, Ethambutol $311 \mathrm{cfu} / \mathrm{ml}$, Pyazinamide $218 \mathrm{cfu} / \mathrm{ml}$. While the efficacy of tuberculosis drugs based on the ability to decrease the blood sedimentation rate (BSR) showed that Rifampicin able to reduce the BSR by $46.5 \mathrm{~mm} / \mathrm{hour}$, Isoniazide $42.3 \mathrm{~mm} /$ hour, Ethambutol $49.5 \mathrm{~mm} / \mathrm{hour}$, Pirazinamide $48.5 \mathrm{~mm} / \mathrm{hour}$. The most effective TB drugs decreased the number of Micobacterium tuberculosis and the rate of sedimentation of blood was Ethambutol.
\end{abstract}

Keywords: Tuberculosis, Pulmonary TB, BSR, TB Drug 
Tuberkulosis (TB) merupakan penyakit infeksi menular yang disebabkan bakteri Micobacterium tuberculosis yang dapat menyerang berbagai organ terutama paru-paru (KemenKes 2016)

Saat ini penyakit Tuberkulosis Paru (TB Paru) masih menjadi masalah kesehatan yang utama di dunia maupun di indonesia. Menurut WHO 2011 insiden kasus tuberkulosis di Indonesia sekitar $4 \%$ dari jumlah pasien tuberkulosis di dunia dan merupakan ke 4 terbanyak setelah India, Cina dan afrika selatan.

WHO 2009 menerangkan bahwa lebih dari 2 miliar orang di dunia atau sama dengan sepertiga warga dunia terinfeksi basil TB (Micobacterium tuberculosis). Data WHO pada tahun 2009, mencatat peringkat Indonesia berada di posisi lima di dunia. Pada Global Report WHO 2010 diperoleh data bahwa di Indonesia terdapat kasus TB pada tahun 2009 sebanyak 294.731, dimana 169.213 merupakan kasus yang hasil uji laboratorium terhadap dahaknya mengandung bakteri tahan asam (BTA), yaitu Micobacterium tuberculosis, sedangkan 108.616 adalah kasus yang hasil uji laboratorium terhadap dahaknya tidak terdapat bakteri tahan asam, 11.215 adalah kasus TB Extra Paru, 3.709 adalah kasus TB Kambuh, dan 1.978 adalah kasus pengobatan ulang diluar kasus kambuh (WHO, 2010).

WHO 2013 melaporkan terdapat 8,6 juta kasus TB (KemenKes 2016)

Dari angka tersebut menunjukan bahwa angka pasien dengan penyakit Tuberkulosis sangat tinggi selain karena penyebarannya yang mudah melalui udara, juga karena kurangnya kesadaran penderita sehingga angka kambuh dan pengobatan ulang masih terjadi.

Jika tidak diberikan pengobatan yang tepat, maka setiap penderita TB Paru aktif dapat menularkan bakteri TB kepada orang lain yang sehat sehingga dapat mempengaruhi peningkatan jumlah pasien TB. Selain itu pengobatan yang tidak tuntas dapat menimbulkan komplikasi berbahaya hingga kematian (KemenKes 2016).

Pengobatan TB paru terbagi atas 2 fase yaitu fase intensif (2-3 bulan) dan fase lanjutan 4 atau 7 bulan. Jenis obat yang digunakan adalah obat utama dan obat tambahan. Obat utama yang di gunakan dalam pengobatan tuberkulosis terdiri dari: Isoniazid, Rifampisin, Pirazinamid dan Etambutol. sedangkan obat tambahan laninnya adalah: kanamisin, amikasin, kuinolon. 
Pada penelitian ini bertujuan mengetahui efektivitas obat TB yang biasa digunakan di Rumah Sakit Islam Asshobirin Terhadap penurunan jumlah bakteri TB, yaitu Micobacterium tuberculosis dan penurunan laju endap darah (LED) Erythrocyte Sedimentation Rate (ESR) atau Blood Sedimentation Rate. Pemeriksaan dahak pada pasien berfungsi untuk menegakkan diagnosa. Diagnosis TB paru pada seseorang apabila ditemukan adanya Micobacterium tuberculosis pada pemeriksaan secara mikroskopis. Bakteri ini berbentuk basil dan bersifat tahan asam sehingga dikenal juga sebagai Basil Tahan Asam (BTA).

Setelah

Micobacterium

tuberculosis menginfeksi paru-paru, maka koloni bakteri segera tumbuh, Hal ini dapat memicu adanya

reaksi imunologis (respon imun), respon imun non spesifik yang akan memainkan peranan,yaitu neutrofil dan makrofag

\section{METODE}

Instrumen penelitian yang digunakan adalah lembaran obsevasi berdasarkan data rekam medik pasien berisi informasi pasien meliputi identitas pasien (umur, diagnosa, jumlah bakteri pada uji dahak dan nilai laju endap darah (LED) serta obat yang diberikan kepada pasien. Rancangan penelitian yang sehingga memunculkan adanya reaksi inflamasi dalam tubuh, dimana makrofag akan memfagositosis bakteri yang menginfeksi.

LED merupakan pemeriksaan untuk menentukan kecepatan eritrosit mengendap dalam darah yang tidak membeku (darah berisi antikoagulan) pada suatu tabung vertikal dalam waktu tertentu, tes laboratorium LED berperan sebagai penunjang diagnosa. Nilai normal pada laki-laki $0-10 \mathrm{~mm} / \mathrm{jam}$ dan perempuan 0-15 $\mathrm{mm} / \mathrm{jam}$ (Ibrahim, dkk.2006). Nilai LED umumnya digunakan sebagai indikator penyembuhan pasien, LED sering meningkat pada pasien aktif, tetapi LED yang normal tidak berarti mampu menyingkirkan tuberkulosis (Perhimpunan Dokter Paru Indonesia, 2006). Nilai LED juga dapat digunakan sebagai indikasi adanya suatu reaksi inflamasi dalam tubuh.

digunakan adalah jenis penelitian kuantitatif deskriptif korelasional dengan pendekatan cross sectional, yaitu melihat hubungan variabel dependen dengan melakukan suatu observasi atau pengukuran pada variabel dependen dan independen yang dilakukan 
secara stimultan atau bersamaan pada satu waktu atau sekali waktu. Cara pengambilan sampel dalam penelitian ini menggunakan teknik non probability sampling yaitu teknik yang tidak memberikan kesempatan yang sama pada anggota populasi untuk dipilih menjadi sampel

\section{HASIL}

Berdasarkan penelitian, diperoleh hasil sebagai berikut:

Tabel 1. Presentase pengguna obat Tuberkulosis Paru

\begin{tabular}{lcc}
\hline Nama Obat TB Paru & N & \% \\
\hline Rifampisin & 32 & 31 \\
Isoniazid & 32 & 31 \\
Etambutol & 23 & 22 \\
Pirazinamid & 17 & 16 \\
\hline
\end{tabular}

Berdasarkan Tabel 1. Terlihat bahwa persentase penggunaan obat terbanyak untuk TB paru adalah Rifampisin dan Isoniazid sebesar $31 \%$,penggunaan
Etambotul sebanyak23\% sedangkan Pirazinamid menunjukkan persentase paling kecil, yaitu sebesar $16 \%$

Tabel 2. Jumlah Micobacterium tuberculosis sebelum dan setelah pengobatan

\begin{tabular}{lccc}
\hline Nama obat & $\begin{array}{l}\text { Jumlah bakteri sebelum } \\
\text { pengobatan }(\mathrm{cfu} / \mathrm{ml})\end{array}$ & $\begin{array}{l}\text { Jumlah bakteri setelah } \\
\text { pengobatan }(\mathrm{cfu} / \mathrm{ml})\end{array}$ & $\begin{array}{c}\text { selisih jumlah } \\
\text { bakteri (cfu/ml) }\end{array}$ \\
\hline Rifampisin & 270 & 74 & 196 \\
Isoniazid & 300 & 87 & 213 \\
Etambutol & 410 & 99 & 311 \\
Pirazinamid & 305 & 77 & 218 \\
\hline
\end{tabular}

Berdasarkan Tabel 2, diketahui bahwa Etambutol memiliki kemampuan dalam menurunkan jumlah bakteri penyebab TB (Micobacterium tuberculosis) paling besar dengan kemampuan menurunkan jumlah bakteri sebesar $311 \mathrm{cfu} / \mathrm{ml}$, kemampuan obat Isoniazid dalam menurunkan jumlah 
Micobacterium tuberculosis sebesar 213 cfu/ml, Pirazinamid sebesar $218 \mathrm{cfu} / \mathrm{ml}$, sedangkan Rifampisin memiliki kemampuan menurunkan jumlah

Micobacterium tuberculosis paling

rendah, yaitu sebesar $196 \mathrm{cfu} / \mathrm{ml}$.

Tabel 3. Penurunan laju endap darah sebelum dan setelah pengobatan

\begin{tabular}{cccc}
\hline Nama obat & $\begin{array}{c}\text { Sebelum pengobatan } \\
(\mathrm{mm} / \mathrm{jam})\end{array}$ & $\begin{array}{c}\text { Setelah pengobatan } \\
(\mathrm{mm} / \mathrm{jam})\end{array}$ & selisih (mm/jam) \\
\hline Rifampisin & 85 & 38.6 & 46.5 \\
Isoniazid & 86.1 & 43.8 & 42.3 \\
Etambutol & 98.5 & 49 & 49.5 \\
Pirazinamid & 102.2 & 54.2 & 48 \\
\hline
\end{tabular}

Berdasarkan Tabel 3. diketahui

bahwa Etambutol memiliki efektivitas

paling besar dalam menurunkan laju endap darah pasien TB, yaitu sebesar 49,5 ( $\mathrm{mm} / \mathrm{jam})$, selanjutnya Pirazinamid yang memiliki kemampuan sebesar 48 $(\mathrm{mm} / \mathrm{jam})$ dan Rifampisin memiliki

\section{DISKUSI}

Pada penelitian ini, sampel yang di gunakan berasal dari 40 pasien TB paru perempuan dewasa rawat jalan di rumah sakit islam Asshobirin tahun 2016 berusia 40-50 tahun, hal ini bertujuan untuk melihat efektivitas obat TB paru terhadap penurunan jumlah bakteri TB dan laju endap darah, digunakan pasien perempuan karena umumnya pasien perempuan lebih disiplin dalam menjalani pengobatan, memiliki pola hidup yang lebih sehat sehingga dapat mengurangi faktor eksternal yang dapat kemampuan sebesar 46,5(mm/jam), sesangkan dari hasil penelitian ini Isoniazid menunjukkan kemampuan paling kecil dalam menurunkan laju endap darah pasien TB, yaitu sebesar $42,3$ ( $\mathrm{mm} / \mathrm{jam})$.

mempengaruhi efektivitas penggunaan obat secara eksternal.

Penelitian lain menunjukkan bahwa infeksi TB paru berada pada usia produktif 27-58 tahun dan semakin dewasa seseorang maka pengalaman dan pengetahuan yang didapat semakin banyak sehingga dapat berdampak pada berhasilnya pengobatan. karena didukung oleh keinginan yang kuat agar cepat sembuh (Silvani dan Sureskiarti 2016), sehingga berdasarkan hal tersebut maka 
usia yang digunakan dalam penelitian ini 40-50 tahun.

Hasil penelitian menunjukkan bahwa obat utama TB paru yang sering digunakan di Rumah Sakit Islam Asshobirin, Tangerang berdasarkan tingkat presentase yang paling sering digunakan adalah Rifampisin, Isoniazid, Etambutol dan Pirazinamid. Jika dilihat berdasarkan dari kemampuan obat TB paru yang digunakan pasien dalam menurunkan jumlah BTA (Basil Tahan Asam) Micobacterium tuberculosis, pada penelitian ini menunjukkan hasil bahwa Etambutol mampu menurunkan jumlah BTA paling besar dibandingkan obat TB paru utama lainnya yang digunakan dalam penelitian ini, yaitu mampu menurunkan jumlah koloni bakteri sebanyak $311 \mathrm{cfu} / \mathrm{mL}$ setelah 3 bulan pengobatan.

Adapun obat TB yang memiliki kemampuan dibawah Etambutol adalah Pirazinamid dengan kemapuan menurunkan jumlah koloni sebanyak $218 \mathrm{cfu} / \mathrm{mL}$ dan Isoniazid sebesar $213 \mathrm{cfu} / \mathrm{mL}$ setelah 3bulan mengkonsumsi obat. Pada penelitian ini Rifampisin menunjukkan kemapuan paling rendah dalam menurunkan jumlah Micobacterium tuberculosis dengan kemampuan menurunkan sebesar 196 $\mathrm{cfu} / \mathrm{mL}$ setelah 3 bulan pengobatan.

Hal ini di duga disebabkan mekanisme kerja obat yang berbeda, aktifitas obat TB didasarkan atas tiga mekanisme, yaitu aktifitas membunuh bakteri, aktifitas sterilisasi, dan mencegah resistensi (DepKes RI 2005).

Target utama Etambutol adalah terganggunya sintesis dinding sel mikroba (Micobacterium tuberculosis) dengan cara mempengaruhi enzim arabinosyl transferase. Arabinosyl transferase merupakan enzim yang berperan langsung dalam pembentukan arabinan yang merupakan salah satu komponen arabinogalaktan pada dinding sel Micobacterium tuberculosis (Pym and Cole 2008).

Aktivitas Etambutol menyebabkan terjadi gangguan sintesis arabinogalaktan sehingga menyebabkan tidak terbentuknya ikatan komplek mycolyl-arabinogalactan-peptidoglycan pada dinding sel. Hal ini menyebabkan peningkatan permeabilitas dinding sel sehingga senyawa aktif obat lebih mudah memasuki sel. Selain itu menyebabkan terjadi penumpukan asam mikolat di dalam sel sehingga menyebabkan kematian sel (Rattan et al).

Hasil penelitian ini juga menunjukkan bahwa Ethambutol memiliki kemampuan paling efektif dalam menurunkan laju endap darah pada pasien TB paru, yaitu sebesar 49,5(mm/jam) setelah 3 bulan pengobatan. selanjutnya Pirazinamid yang 
memiliki kemampuan menurunkan LED sebesar 48 (mm/jam) dan Rifampisin sebesar 46,5(mm/jam), Pada penelitian ini Isoniazid (INH) menunjukkan kemampuan paling kecil dalam menurunkan laju endap darah pasien TB, yaitu sebesar 42,3 ( $\mathrm{mm} / \mathrm{jam})$.

Salah satu proses diagnosis penyakit Tuberkulosis lainnya yaitu dengan pemeriksaan darah seperti hitung jumlah leukosit dan laju endap darah (LED). Laju Endap Darah (LED) dibutuhkan karena dapat dipakai sebagai indikator tingkat penyembuhan pasien.

\section{SIMPULAN}

Hasil penelitian menunjukkan bahwa obat TB paru yang sering digunakan adalah Rifampisin dan Isoniazid dengan presentase sebesar $31 \%$, Etambotul sebesar $23 \%$ sedangkan Pirazinamid menunjukkan persentase paling kecil, yaitu sebesar $16 \%$

Efektivitas obat TB paru berdasarkan kemampuan menurunkan jumlah Micobacterium tuberculosis, diperoleh bahwa Etambutol memiliki kemampuan paling besar, yaitu 311 cfu/ml, Isoniazid sebesar $213 \mathrm{cfu} / \mathrm{ml}$, Pirazinamid sebesar $218 \mathrm{cfu} / \mathrm{ml}$,
LED yang meningkat menunjukkan bertambahnya jumlah leukosit berkaitan dengan fungsinya sebagai pertahanan, sehingga pengendapan darah melaju lebih cepat karena bertambah jumlah sel darah (Tahumuri et al 2017) sehingga pada penelitian ini menunujukkan bahwa Ethambutol mampu menurunkan angka LED lebih besar dibandingkan Pirazinamid, Rifampisin dan Isoniazid (INH), hal ini menunujukkan bahwa menunjukkan adanya penurunan inflamasi pada tubuh pasien setelah menjalani 3 bulan pengobatan.

sedangkan Rifampisin memiliki kemampuan menurunkan jumlah Micobacterium tuberculosis paling rendah, yaitu sebesar $196 \mathrm{cfu} / \mathrm{ml}$

Etambutol memiliki efektivitas paling besar dalam menurunkan laju endap darah pasien TB, yaitu sebesar 49,5 (mm/jam), Pirazinamid sebesar 48 (mm/jam), Rifampisin sebesar 46,5( $\mathrm{mm} / \mathrm{jam})$ dan Isoniazid sebesar 42,3 (mm/jam). 


\section{DAFTAR PUSTAKA}

Brunton L, Parker K, Blumenthal D, Burton I. Manual of Pharmacology and Therapeutics. McGraw-Hill Companies 2008 p 784-793

Debbie S, Retnoningrum, Roga F, Kembaren. 2004. Mekanisme Tingkat Molekul Resistensi Terhadap Beberapa Obat pada Mycobacterium Tuberculosis. Acta Pharmaceutica Indonesia vol XXIX no 3, 2004 p 9295

Departemen Kesehatan RI. 2005. Pharmaceutical Care Untuk Penyakit Tuberkulosis. Direktorat Bina Farmasi Komunitas dan Klinik Direktorat Jenderal Bina Kefarmasian dan Alat Kesehatan.

Gillespie SH. Evolution of Drug Resistance in Mycobacterium Tuberculosis : Clinical and Molekuler Perspective. Antimicrobial agents and chemotherapy 2002. p $267-274$

Ibrahim N, Aprianti S, Arif M, Hardjoeno. 2006. Hasil Tes Laju Endap Darah Cara Manual dan Automatik. Indonesian Journal of Clinical Pathology and Medical Laboratory, Vol. 12, No. 2, Mar 2006: 45-48

Palomino JC, Leao SC, Ritacco V. 2007 Tuberculosis 2007 from Basic Science to Patient Care : Argentina

Perhimpunan Dokter Paru Indonesia. 2006. Tuberkulosis, Pedoman Diagnosis \& Penatalaksanaan di Indonesia. Available from:http://klikpdpi.com/konsensus/ Xsip/tb.pdf [accesed: 12 february 2018)

Pym AS, Cole S. 2008. Mechanism of Drug Resistance in Mycobacterium Tuberculosis. In Wax RG, Lewis K, Salyers AA, Taber H. Bacterial Resistance to Antimicrobals. Denver 2008 p 313-331
Rattan A, Kalla A, Ahmad N. Multi Drug-Resistant Mycobacterium Tuberculosis : Molekuler Perspectives. diakses dari http://www.cdc.gov/ncidod/EID/vol4no 2/rattan.

Silvani H, Sureskiarti E .2016. Hubungan peran aktif keluarga sebagai pengawas minum obat (PMO) Dengan angka kekambuhan TB paru di ruang seruni RSUD abdul wahab sjahranie Samarinda. Jurnal Ilmu Kesehatan.Vol.4 No. 2, Desember 2016

Tahumuri A, Wongkar MCP, Rotty LWA. 2017. Gambaran Laju Endap Darah Dan C-Reactive Protein Pada Pasien Tuberkulosis Paru Di Manado 2016. Jurnal Kedokteran Klinik (Jkk), Volume 1 No 3 , April 2017. 
